Revista Iberoamericana, Vol. LXXVII, Núm. 234, Enero-Marzo 2011, 41-57

\title{
DEL NACIONALISMO COMO TRETA DE LA IMAGINACIÓN IDENTITARIA EN 450 AÑOS DE GUERRA CONTRA EL IMPERIALISMO, DE HÉCTOR GERMÁN OESTERHELD Y LEOPOLDO DURAÑONA
}

\author{
POR

\section{Héctor Fernández L’Hoeste \\ Georgia State University}

Publicada en la montonera revista El Descamisado entre los años de 1973 y 1974, e ilustrada con destreza por Leopoldo Durañona (1938-), la historieta seriada 450 años de guerra contra el imperialismo figura como uno de los más firmes empeños de Héctor Germán Oesterheld (1919-¿1978?), el gran guionista del historietismo argentino, por rendirle un ajuste de cuentas a los desafueros expansionistas de potencias europeas y americanas. ${ }^{1}$ A primera vista, la narrativa de esta serie destaca por su ademán progresista, bastante conspicuo en el contexto ideologizante de la época. Las imágenes de Durañona suelen ser impactantes, ${ }^{2}$ pero la mayor parte de la fuerza narrativa del relato proviene, sin lugar a duda, de la labor del guionista, quien se aventura a lidiar con episodios históricos de manera inusitada, teniendo en cuenta las convenciones gráficas de la época. Con el tiempo, la figura de Oesterheld, cuyo paso por los centros de tortura está documentado en Nunca más, en voz de Eduardo Arias, o por personajes como Jacobo Timmerman, en Prisionero sin nombre, celda sin número, ha adquirido dimensiones míticas. Mediante la trama de esta serie de historietas, Oesterheld problematiza de manera sagaz materias concernientes a temáticas de raza, género y, por supuesto, clase, de forma anticipada a entendimientos culturalistas. En particular, lo de la complejización de la clase social era de esperar en el contexto político de la época, marcado por el regreso de Perón a la Argentina, y los vínculos de Oesterheld a movimientos clandestinos de

1 Nacido en Buenos Aires el 23 de julio de 1919, Héctor Germán Oesterheld es considerado el más importante guionista del historietismo argentino. Su obra goza de gran aceptación en el marco de la industria cultural argentina. El 27 de abril de 1977, fue secuestrado por las Fuerzas Armadas en la ciudad de La Plata. Tras ser visto con vida por última vez durante la Navidad de ese año, se desconocen los detalles de su muerte; se conjetura que habría fallecido en 1978.

2 Nacido en Buenos Aires en 1938, Leopoldo Durañona es conocido por su aporte a casas estadounidenses como Warren, Marvel y Dark Horse. En el caso de Warren, gracias a su labor en publicaciones como Eerie, Creepy y Vampirella, cosechó cierto renombre como ilustrador. Su producción se caracteriza por un trazo fuerte y nítido, de corte realista. Maestro del storyboard, Durañona suele ampararse en primeros planos con empleo generalizado de luces y sombras. En el caso de 450 años, enfatiza el corte de la figura humana, enmarcándola a menudo en situaciones a contraluz, en las que prima el uso del claroscuro. 
oposición. En términos generales, la crítica del guionista aparenta ser progresista y liberadora, enjuiciando lecturas oficialistas -léase, bonaerenses y gobiernistas- de la historia argentina. Al fin y al cabo, la narrativa desarrollada por ambos autores lidia con temas que, en aquellos momentos, no figuraban como prioritarios dentro del marco sociocultural argentino, casi totalmente acaparado por las tensiones resultantes del exacerbado antagonismo entre el peronismo y otras fuerzas políticas.

Sin embargo, un examen más atento delata cómo el proyecto de Oesterheld, en particular, dista de ser revelador. Las imágenes funcionan, pero el orden escrito sugiere otros matices. En el contexto de raza, patentizado por el cubrimiento de episodios legendarios como el martirio del inca Tupac Amaru y el sacrificio de contingentes negros durante la campaña libertadora de San Martín y otras guerras, Oesterheld se limita a ratificar la supuesta homogeneidad europea de la población argentina, distanciándose de una representación más fidedigna de la pluralidad nacional. En materia de género, luego de apenas reconocer la presencia de mujeres durante los primeros años de la gesta poscolonial -como habría de esperarse, las pocas que alcanzamos a vislumbrar pertenecen a la burguesía porteña, de manera que su intervención viene henchida de desaprobación-, el guionista se acoge de manera indulgente al tipo de las soldaderas mexicanas, adaptándolas al contexto austral; es decir, sin sugerir novedad alguna, reiterando una visión masculinista del proceso histórico. Y en términos de clase, el cariz por excelencia para alguien involucrado en un esfuerzo de índole revolucionaria, pese al presunto enjuiciamiento de versiones oficiales de la historia, la reivindicación del papel político de las provincias del interior y la inculpación de las élites porteñas, Oesterheld se acoge al dibujo de Durañona para diagramar argentinidades títeres, siempre al servicio de potestades foráneas. De esta manera, su esquema se remite a una diagramación de alteridades desiguales, entre las que siempre prima la mano ajena. En otras palabras, Oesterheld se rehúsa a reconocer la responsabilidad compartida en el fracaso de la patria argentina. Bajo este esquema, la nación gaucha yace asediada de manera constante por una sucesión de rufianes e intereses nefastos, siempre maquinando en su contra, perennemente en busca de una manera mañosa de arrebatarle sus recursos, el legítimo patrimonio del pueblo. Al igual que en otras producciones de la época, este relato gráfico hace acopio de maniqueísmo y queda exento de autocrítica; de idéntica forma, siempre funciona dentro del marco ficticio, imaginativo, de una gran patria americana, razón por la cual hace agua. El afán de ciertos cuadros políticos por situar sus esfuerzos dentro del cerco de una campaña revolucionaria continental siempre se condujo en este sentido. Semejante proyecto, si bien puede endilgársele a la saga bolivariana, dista de tener puntos de contacto fehacientes con la población rioplatense de comienzos del siglo diecinueve, tan ajena en ese instante a un espíritu latinoamericanista. Pese a las posteriores maniobras de San Martín, llegando hasta Lima y Guayaquil, los esfuerzos de las nacientes Provincias Unidas convergieron más en torno a una definición del control de la cuenca ribereña. A ojos de buena parte del resto de Latinoamérica, sería

Revista Iberoamericana, Vol. LXXVII, Núm. 234, Enero-Marzo 2011, $41-57$
ISSN 2154-4794 (Electrónico) 
sólo a partir de posteriores descalabros, como el episodio de las Malvinas, los repetidos desajustes económicos y el horror de la dictadura militar, que la Argentina comenzaría a reconocerse, de manera generalizada, como más de este lado del océano que como un rezago fortuito de su ancestro europeo.

En este sentido, esta historieta de Oesterheld y Durañona ilustra bien el poder del arraigo de la noción de nación -al igual que el del prejuicio letrado-. Sus esfuerzos por disputarle la potestad identitaria al Estado jamás logran rebasar los límites de ciertas ideas. A veces, incluso se angustian por defenderlas, sin atreverse a esgrimirlas de manera irreverente u original, inyectándoles un nuevo significado contradictorio de las lecturas oficiales. En 450 años, la diagramación de la historia nacional es tan proclive a una compartimentación episódica, que impide expansión identitaria alguna. Al hablar del origen de la divisa albiceleste, por ejemplo, el guionista explica cómo, desde su punto de vista, la primera aparición de la misma viene teñida de infamia, pero jamás se arriesga a ofrecer una alternativa -en cuestión de anécdota o uso- para el pabellón nacional. En materia de imaginación identitaria, pese a su gran diferencia en escala, los imperios, las naciones y las regiones se redimen con argumentaciones análogas: fabricando ideas inspiradoras de pasiones ciegas y arribistas, aunadas a la celebración de los símbolos patrios -banderas multicolores, himnos altisonantes, historias oficiales rebosantes de sufrimiento, mitologías aglutinantes, etc.-, los cuales, en el caso latinoamericano, en más de una ocasión identifican y celebran al Estado mientras ignoran a buena parte de la nación. Esta obra es prueba fidedigna del carácter engañoso de semejantes tretas de la identidad.

Agrandes rasgos, el trabajo del guionista argentino se cimienta en torno a tres grandes ejes temáticos. En primera instancia, está su aparente preocupación por ofrecer una versión alterna de los hechos, confiriéndole prioridad a la clase como categoría identitaria destacada. Dichos relatos, cabe anotar, fungen de médula narrativa, con el ocasional entrelazamiento de asuntos de raza y género como ejes apéndices. En buena parte, esta representación se apoya en una diagramación selecta de rivales de turno: en un principio, el ejército realista y un decadente imperio peninsular; poco después de alcanzada la separación de España, la zarpa anglosajona; y, como último recurso, el avasallamiento del capitalismo multinacional, personificado por los intereses estadounidenses. De manera infortunada, al tiempo que Oesterheld fustiga a los enemigos de la patria, legitima una concepción de nación albergadora de numerosos aspectos en común con versiones identitarias promulgadas y celebradas por el Estado argentino. En otros términos, muy a pesar de su esfuerzo por proyectar argentinidades alternas, la concepción de patria de Oesterheld no alcanza a escaparse por completo de las garras del mito oficial. En manos del guionista, la idea de patria parece una sola, concreta y diáfana, apegada a un linaje de añejo arraigo. Cuando, en uno de sus arrastres fervorosos, Oesterheld cita a Martiniano Chilavert -"un hombre que se siente patria”, reafirma el narrador-, "Mi única ambición es ser siempre digno de pertenecer a mi esclarecida patria, y del aprecio

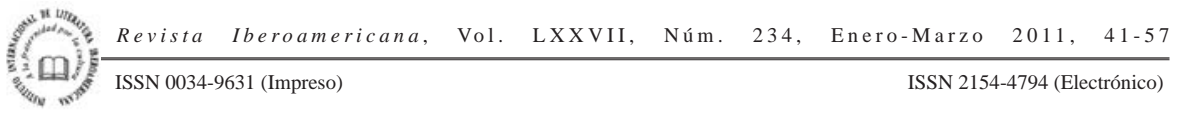


de los hombres de bien”, sustenta la impresión de compartir un imaginario íntegro y sin discontinuidades, desde 1820 hasta el presente, circunstancia contrarrestante de cualquier algarada de discordia nacional. ${ }^{3}$ Por otro lado, el guionista se empecina tanto en representar alteridades malignas que su quehacer identitario hereda visos inescrutables, según los cuales dichas otredades se revelan inertes y macizas, carentes de ductilidad, inmovilizadas ante la seriedad del compromiso de su destino histórico.

En Argentina: Stories for a Nation, Amy Kaminsky sugiere una exploración de las figuraciones de la identidad gaucha en el contexto de las imaginaciones norteamericanas y europeas en la que "It is critical that we attend to the nuances of the processes of othering”. De esta manera se esfuerza por indicar cómo se le puede restar capacidad de emitir una respuesta efectiva y fehaciente al ser abyecto (18). En este sentido, su meditación en torno a la configuración de identidades argentinas no puede ser más oportuna. No prestarle atención a los matices de la alteridad nos conduce, de hecho, a un callejón sin salida. En este caso, cada desplazamiento de la misma -tanto en el papel de sujeto, según pretende Oesterheld con su relato montonero, como en el rol de objeto, según aparecen las negritudes y mujeres en su narración- queda congelado de manera inmediata y casual, entorpeciendo una viable oportunidad de respuesta y postrando casi por completo cualquier tentativa de reacción interpretativa. Todo queda encerrado en extremos, resumido en opuestos, $\mathrm{y}$ al cabo de unas cuantas aproximaciones, el mundo comienza a entreverse de forma holgada -e ilusoria- en focos encontrados.

Las demás líneas narrativas de Oesterheld, pese a verse afectadas por semejante disposición maniquea y su afán de configurar el mundo con distintivos matices de extremos opuestos, se orientan hacia una complejización de la diferencia racial, y una crítica distante y ensimismada de la diferencia de género. Lo de la raza se asoma de formas variadas en la historieta: en el relato de la población indígena, desposeída y desmañada; en el recuento del sufrimiento de los esclavos, ya sea de forma independiente o como miembros del ejército libertador; y en un muy tímido reconocimiento de ambiciones mestizas, encarnado de manera timorata en denuedos gauchos. En el contexto de la producción cultural austral de los años setenta, más ocupada en exteriorizar los intereses y las motivaciones de las clases medias y altas, este anhelo por problematizar la diferencia étnica es digno de encomio. En materia de historietas, si algo triunfaba en Argentina a comienzos de los años setenta era la obra de Joaquín Salvador Lavado. Surgían Crist, Mandrafina y Sendra, pero ya Quino estaba consagrado. Postulándose como niña progre, Mafalda (1964-1973) se encargaba de difundir y universalizar los valores de clase de la

\footnotetext{
3 Toda cita de esta obra de Oesterheld y Durañona se remite a Latinoamérica y el imperialismo, 450 años de guerra, la compilación de las historietas de El Descamisado publicada por Doeyo y Viniegra Editores en Buenos Aires en 2004. De manera infortunada, dicha edición carece de numeración en su facsímil de las historietas, las cuales aparecen identificadas según su fecha de publicación. La cita de Chilavert, por ejemplo, corresponde al homónimo episodio No. 42 de El Descamisado, del 5 de marzo de 1974.

Revista Iberoamericana, Vol. LXXVII, Núm. 234,
ISSN 0034-9631 (Impreso)
} 
pequeña burguesía porteña, haciendo caso omiso de otras perspectivas. En este marco, la diferencia de raza se limitaba a orientales enigmáticos y pieles rojas armados hasta los dientes, a la manera de un buen número de cómics del mercado internacional. Por ende, dentro de semejante contexto historietístico, el hecho de que Oesterheld alcanzara a formular temáticas de corte etnográfico fundamentadas en lecturas de historia nacional, propone, hasta cierto punto, un adelantado.

Lo del género, en cambio, apunta en otra dirección. Las obras de Oesterheld no se destacan por una representación fehaciente de una temática de género. De hecho, El Eternauta, la historia de una invasión alienígena elaborada en colaboración con el dibujante Francisco Solano López -y luego con Alberto Breccia-, y quizás el mayor logro de Oesterheld en el ámbito de la historieta argentina, ejemplifica de lleno el carácter masculinista de su quehacer guionístico. En El Eternauta, las mujeres casi no aparecen; su aporte a la trama es tangencial y remoto. Como personajes, tienen escasísimo desarrollo. Su presencia no encarna mayor protagonismo y su accionar lejos está de cuestionar los confines y las responsabilidades de un ambiente doméstico. Ahora bien, dicha configuración tal vez pueda ser justificada por la disposición inicial de la ciencia ficción en cuanto a género (ante Gorodischer) y la factible consideración oesterheldiana de un público adolescente y joven. En 450 años, sin embargo, hay algo análogo. Si bien el guionista se animaba a festejar el mito de Eva Perón, difícil le quedaba imaginarse mujeres en roles centrales en cualquier otra de sus historias. De ahí que llame tanto la atención la incorporación de la dirigente a los ardores de 450 años.

Vale la pena anotar también que, antes de redactar este ajuste de cuentas a la historia nacional, Oesterheld exploró el potencial de la adaptación historiográfica del mundo político argentino en sendas historietas, llamadas La historia de los villeros: de la miseria a la liberación y Perón: la reconquista del gobierno. Hacia la toma del poder, ambas ilustradas por Durañona con un estilo premonitorio de su trabajo en 450 años. La primera es un relato etnográfico, mediante el cual, al tiempo que ofrece una crónica de su origen urbanístico, Oesterheld reitera el compromiso de las poblaciones villeras con los cuadros peronistas. La segunda es un poco más extensa -y Durañona hasta incluye ametralladoras y pasacalles peronistas-. Ofrece una explicación del accionar de Perón desde el inicio mismo de su exilio hasta el momento de su regreso victorioso; inclusive se esfuerza por justificar el frustrado intento de retorno del caudillo argentino durante la presidencia de Illia como parte de una estrategia de confrontación. El tono épico del recuento montonero, grandilocuente y cabalmente argentino, alcanza a testimoniar la ignominia de la tortura, sin sospechar acaso que, en un futuro próximo, el guionista mismo correrá con idéntica suerte. De cualquier manera, de lo que no cabe la menor duda es que, a partir de ambas historietas, Oesterheld logró una voz. El ensayo le sirvió para comprender el potencial del medio historietístico como herramienta comunicativa, pero lo más acertado fue su desarrollo de un método personal para la adaptación historiográfica. En síntesis, esta producción, de tan escasa envergadura y

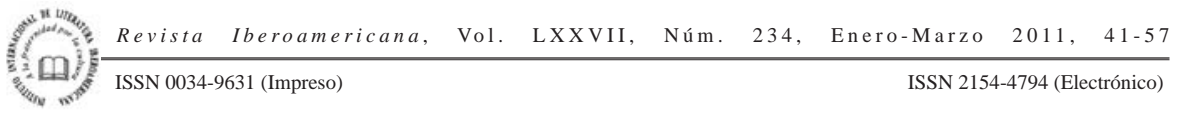


efímera vigencia, sirvió de antesala al desordenado pero conveniente cotejo del relato argentino esbozado en 450 años.

Para comprender la dinámica interna de la propuesta de Oesterheld, conviene un análisis pormenorizado de sus planteamientos. Un primer vistazo al facsímil de la historieta nos enseña que, con el fin de esclarecer su objetivo desde un primer momento, Oesterheld prologó las imágenes de Durañona con la siguiente leyenda: "Vamos a contar la historia de cómo nos robó el imperialismo". ${ }^{4} \mathrm{El}$ "nos" hermana al narrador con una América víctima, equiparándole con poblaciones desprotegidas y maltratadas, sin tomarse siquiera el trabajo de admitir las marcadas diferencias -identitarias e históricas, entre otras- encarnadas por la población argentina. Si la experiencia argentina representaba una situación anómala en comparación con la historia y el contexto de otras naciones latinoamericanas, esto no era materia de consideración, parecen sugerir estas palabras. Todo se reducía a un común denominador: la explotación a manos del enemigo. Partiendo de este enfoque, los desengaños ajenos habrían de convertirse en propios. El título acompañante -“América Latina, 450 años de guerra”- y la reiterada alusión a los desmanes del imperialismo en el párrafo posterior clarifican, desde un inicio, la aguerrida vocación de los autores.

Las imágenes comienzan con juicios en contra de España, meta asequible en el idiosincrásico contexto austral. Según nos recuerda Kaminsky con respecto a España, para los argentinos, como añeja potencia colonial, el chapetón invasor encarnaba un significado diferente al compartido en el resto de Europa (21). Dista un tanto este significado decimonónico del que hoy han adquirido los capitales ibéricos tras la acometida neoliberal de los años noventa. A fines de la saga de la independencia, a diferencia de Francia, emisora de un formidable magnetismo cultural, y el Reino Unido, fuente irrestricta de capital, España era vista por los gauchos como el ejemplo preciso a desdeñar por la crisis en la que estaba sumida. Para validar su alegato e inyectarle algo de sentimiento americanista, Oesterheld comienza hablando de mayas, de calendarios incas, de azogue, de robo de plata y oro, y contrabando de esclavos. Termina su primer episodio, publicado el 24 de julio de 1973, hablando de... Perón. Jamás se explica qué tiene que ver el caudillo argentino, tan indiscutiblemente usufructuario de una genealogía europea-ia diferencia de los acompañantes dibujos, Perón es representado con una fotografía, esgrimiendo el clásico ademán retórico!--, con un pasado y una tradición ajenos a su enunciación de nacionalidad y clase. Para este efecto, parece sugerir la narrativa, ha de bastar con el supuesto enjuiciamiento del "azote del imperialismo". Luego, en el siguiente episodio, buscando reiterar el sufrimiento amerindio, Oesterheld dedica sus esfuerzos al cubrimiento del martirio tupamaro. ${ }^{5}$ Desde este mismo episodio hasta la posterior viñeta, encargada

4 No. 10 de El Descamisado, del 24 de julio de 1973.

5 “La rebelión de Tupac Amaru”, No. 11, del 31 de Julio de 1973.

Revista Iberoamericana, Vol. LXXVII, Núm. 234, Enero-Marzo 2011, $41-57$
ISSN 2154-4794 (Electrónico) 
de rememorar el ocaso de las negritudes argentinas, la diferencia étnica surgirá diligente. Los dos primeros cuadros de la historieta aluden de manera irremisible a la destrucción de una tradición oral, suplantada por la grafía europeizante: en un recuento fatídico de los suplicios de la época, delinean el arrancamiento, con un atroz tirón, de la lengua indígena. En consecuencia, pudieran hipotetizar los lectores, las imágenes de Durañona y las palabras de Oesterheld lucharán por ellos. La carencia de un contexto común -o tan siquiera el intento por justificarse- es irrelevante. La historieta narra el enfrentamiento del líder indio con el corregidor Arriaga y el subsiguiente ajusticiamiento del español. Hasta plasma la solidaridad de Micaela, compañera del inca. Pero luego, remitiéndose a la sempiterna convención judeocristiana, plantea la traición de un lugarteniente tras el asalto al Cuzco, gracias a la cual Tupac Amaru es capturado y llevado a la mazmorra. Su cuerpo resiste el tormento, pero el hacha llega pronta. Ahora bien, a juicio de los autores, el protagonismo del mártir inca, tan extraño a la tradición porteña, parece bastar para ratificar los lazos entre una América indígena y una población de inmigrantes. La distancia entre la realidad andina y el eurocentrismo bonaerense jamás se despeja. Del descuartizamiento tupamaro se pasa al "acogotamiento comercial” y el malogro de las primeras señas de industrialización en la cuenca rioplatense-cortesía de los peninsulares, según el narrador- sin ofrecer el más remoto asomo de duda. El desliz no ha de haber pasado desapercibido, pues, luego de enfatizar su afinidad por el indio, la narrativa opta por nuevos linderos, más conformes con las motivaciones de clase de los innovadores montoneros: el capitalismo desmedido personificado por los ingleses.

Una de las principales venas narrativas de Oesterheld es la redoblada complicidad de la oligarquía porteña con las potencias extranjeras. Sin semejante nexo, difícil sería articular una crítica del desigual orden social austral desde una ferviente alineación revolucionaria. En este sentido, el guionista es mucho más consecuente que en el tratamiento de asuntos de raza o género. Oesterheld aprovecha las invasiones inglesas de 1806 y 1807 para abultar su repertorio de protagonistas: por un lado, el enemigo inglés; por otro, la clase dirigente porteña, compendiada en altos funcionarios y comerciantes; y aún por otro, el pueblo, descrito de manera reductista, manipulado y traicionado por la dirigencia. De forma habilidosa, Oesterheld se ampara en un mecanismo narrativo de gran efectividad, gracias al aporte del medio ilustrado: con el remoquete de "Juan", un "Juan" cualquiera, propone a un joven, un muchacho humilde, como defensor de la primera invasión; luego, ensancha la figura y nos presenta a Juan Paisano y Juan Esclavo, adalides de una defensa postrera. ${ }^{6}$ En el primer caso, Durañona dibuja un efebo de rostro juvenil, casi angelical; en los otros, enfatiza el atuendo campestre y la musculatura, de manera respectiva. Tanto el Juan inicial como Juan Paisano caen víctimas de las balas. Juan Esclavo, en cambio, sobrevive. Su supervivencia está bien justificada. Le sirve a

6 “El Pueblo echa al Invasor Inglés”, No. 14, del 21 de agosto de 1973.

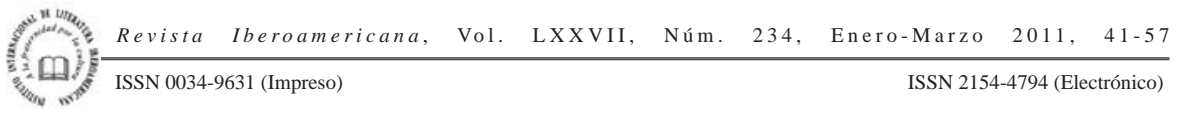


Oesterheld para denunciar la hipocresía de las clases dirigentes, las cuales, tras la lucha, sortearon la liberación de setenta esclavos, haciendo caso omiso del resto (Andrews 618). Esta primera aparición de un afroargentino apunta a la vocación incluyente de la narrativa oesterheldiana, pero, como he conjeturado en párrafos anteriores, todo es materia de simulación. Oesterheld está más interesado en denunciar cómo, después del tratado de Apodaca-Canning, la invasión francesa a España y la cándida intervención de algunos ilustrados locales se da la Revolución de Mayo; en términos prácticos, la legitimación de "un cambio de amo": del yugo español al comercio anglosajón. Lo de la diferencia de raza, tan accidentada en las imágenes de Durañona, en realidad le tiene sin cuidado. Lo vital es que la figura de Juan Esclavo se preste para una dilatada analogía. Si los ingleses son los nuevos amos, sin distinción de nacionalidad, todo porteño de seguro es esclavo, colige la narrativa. Al fin y al cabo, ¿de qué sirve la independencia si toca obtenerla a costa del amparo británico? Los alardes de autosuficiencia de quien aún no reconoce limitaciones, ni el pragmatismo de ciertas concesiones políticas a la hora de deshacerse de un imperio, denotan el extremismo del libretista y, hasta cierto punto, apuntan hacia ciertas instancias de la argentinidad aprovechadas por el Estado para argüir una imagen superior de la nación. En su afán por denunciar lo ajeno, Oesterheld ignora cómo, de cierta manera, convéngale o no, comparte algunas falacias del oficialismo. En síntesis, su autosuficiente concepción de la patria, un tanto aislacionista, se apoya en el "verso" nacional. Pese a los múltiples Juanes, tan untados de pueblo, con siluetas tan heroicas, la construcción de nación del guionista dista de hacer, de forma seria y capacitada, acopio de humildad. En otras palabras, el hermanamiento visual de los Juanes -el paisano y el esclavo comparten tres cuadros angustiosos- frente a enemigos pérfidos y con cara de vampiro sólo se presta para extremos. Hay poco espacio para la moderación en el proyecto de Oesterheld. Sus imaginarios hacen alarde de autonomía, pero hacen alarde obrando la argentinidad según pautas impuestas por cronistas previos.

A partir de este instante, Oesterheld comienza a cimentar su diagramación de la nacionalidad con la oposición entre la metrópoli y el interior. Según colige el relato, este último promete una fórmula más verosímil de la patria. Los mapas incluidos así lo corroboran, resaltando su ubicación. ${ }^{7}$ Buenos Aires, aparte de ser capital, es egoísta, es invasora. Es por ello que una buena parte de los esfuerzos de la dupla creativa se remite a justificar una lectura benévola del aminorado rol del interior del país. No obstante, a lo largo de su compendio de una Argentina impúbera, a Oesterheld se le cuelan dos contradicciones: por un lado, según señalé antes, legitima el surgimiento de la escarapela albiceleste desde la coyuntura morenista; por otro, al plasmar la arenga revolucionaria del prócer Juan José Castelli ante los pueblos aborígenes, pinta indígenas balbuceantes,

7 En “La ‘tercera’ Invasión Inglesa”, No. 15, del 28 de agosto de 1973; “Artigas: la Patria Grande”, del No. 20, del 2 de octubre de 1973; y “Rosas (Primera parte)” No. 29, del 4 de diciembre de 1973.

ISSN 0034-9631 (Impreso) 
ávidos de aguardiente. ${ }^{8} \mathrm{Al}$ referirse a la bandera, el guionista revela su incapacidad de imaginarse un festejo de la individualidad argentina exento de la coloración oficial (o de impugnar el pasado y ofrecer una gama alterna). En este sentido, su afán de patria, de disquisición identitaria, se ciñe a la legitimación de la simbología estatal. Lo de Oesterheld, en este sentido, no es afán de engrandecer la bandera, o de emplearla de manera irreverente, confiriéndole un matiz redentor. Con los símbolos patrios no se juega, parece aseverar la crónica. ${ }^{9}$ La bandera, valga la pena la aclaración, sirve para esgrimir una constante oesterheldiana: la de los antipueblo, la antinación. Partiendo de la bandera, corresponde ensalzar el orden binario, para que quede claro, de una vez por todas, quiénes son los malos: quienquiera que se oponga al pueblo, amén de la voluntad del mismo. Con portar el pabellón nacional no basta; ya existe una tradición de traidores, conjeturan los cronistas.

En el segundo caso, el desliz impacta. En estos episodios, aferrados a la significación de la representación indígena, las imágenes contrastan con las previas de Tupac Amaru, tan valeroso e intachable. En esta ocasión, los amerindios parecen entes insulsos, incapaces de distinguir entre la oportunidad de luchar por la reiterada patria grande y el déspota ultramarino. Son manipulados por el discurso político cual niños incautos, refrendando la miopía del colonizador europeo, defensor del buen salvaje. En cuestión de unas cuantas páginas, con la llegada de la independencia, a la manera de la desacreditada clase pudiente, Oesterheld saca a relucir una interpretación menos conciliadora de los indígenas: al igual que los europeos, los ve como seres carentes de conciencia política, eternamente inmaduros. Por algo no responden a los llamamientos de Castelli. En otras palabras, la narrativa se traiciona a sí misma, imprimiéndole a los incas el desdén previamente criticado en los peninsulares. Según este punto de vista, si el interior y el desierto estaban habitados por seres inocuos carentes de imaginación política, de cierta manera se comprende porqué se dieron los hechos de forma contraria a los intereses del pueblo gaucho.

Con la figura de Bernardino Rivadavia, a quien la historieta le concede generoso protagonismo, comienzan a cimentarse dos tradiciones de la inequidad nacional: el abandono del aparato industrial del interior del país, figurado por una angustiada madre que, al acabarse la demanda bonaerense gracias al influjo de mercancías baratas provenientes de Gran Bretaña, sufre al explicarle a su hija cómo el telar no va a bastar para procurar alimentos; y el acostumbrado atropellamiento de los derechos humanos,

8 Nos. 15 y 16, del 28 de agosto de 1973 y del 4 de septiembre de 1973, de manera respectiva.

9 Para concebir el grado de arraigo de la simbología patria en Argentina, conviene recordar el escándalo producto de la versión rock del himno nacional por Charly García, en flagrante alusión a los norteamericanos alardes de Hendrix. De hecho, a raíz de este percance, García debió sortear un juicio por "ofensa a los símbolos patrios”. Para mayor información a este respecto, ver Vargas Vera, René. "Charly García y el himno”.

$\begin{array}{llllll}\text { Revista } & \text { Iberoamericana, Vol. LXXVII, Núm. 234, } & \text { Enero-Marzo } & \text { 2011, } & 41-57 \\ \text { ISSN 2154-4794 (Electrónico) }\end{array}$ 
en un principio, gracias a la Comisión Extraordinaria de Justicia patrocinada por Pedro José Agrelo, Vicente Echeverría y Miguel de Yrigoyen. Como es de esperarse, la mujer aparece ceñida al ámbito doméstico, mientras que la Comisión sugiere un inicio para el desmán militar. Merced al aprovechamiento del papel de Rivadavia, queda por sentado que, si para allanar en un barrio de gente adinerada hace falta una orden, "para allanar una casa en la villa basta y sobra el patadón a la puerta”. ${ }^{10}$ Este esquema -esta ligazón entre las injusticias del pasado y los desmanes del presente-se repite de manera concertada en la mayor parte de las entregas, pues una de las prioridades historiográficas de Oesterheld es la de trazar vínculos incontrovertibles entre tiempos anteriores y la contemporaneidad. Pese a su anhelo por vincular a Isaac Rojas, Pedro Aramburu y Alejandro Lanusse con los verdugos del 25 de mayo de 1810, El Descamisado, surgida en el momento del Gran Acuerdo Nacional, resultaría aún más premonitoria de lo que cualquiera de ambos autores habría de sospechar. Con el paso del tiempo, tristemente, lo de la tortura se convertiría en una de las formas más recordadas del accionar de la argentinidad.

Tal vez lo francamente novedoso radique en el empecimiento de Oesterheld en “resucitar” al negro, una versión identitaria austral de muy escasa figuración. Al fin y al cabo, una de las mayores ventajas del cómic, junto a su fuerza argumental, es su capacidad de materializar presencias opacadas o borradas en el recuento oficial. Gracias al dibujo, la negritud argentina, de accidentada manifestación en la oferta cultural albiceleste, recobra vida. ${ }^{11}$ A primera vista, el aporte del guionista es nobilísimo, pues denuncia cómo la oligarquía se benefició incluso del enlistamiento de negros en el Ejército de los Andes, a una tasa de trescientos pesos por cabeza, precio que, por su magnitud comercial en el mercado de aquella época, describía apenas a una minoría de la población esclava. De cualquier forma, darle presencia a una negritud argentina conlleva un auténtico prodigio, teniendo en cuenta el grado casi absoluto de desvanecimiento de esta etnia en la semblanza oficial. Hasta hoy día no existe a ciencia cierta un juicio unánime para explicar la desaparición de la población negra en el relato nacional argentino. Las fuentes

10 “Rivadavia, Garantía para los Ingleses”, No. 17, del 11 de septiembre de 1973.

${ }^{11}$ Según Judith Gociol y Diego Rosenberg, la negritud aparece en la historieta argentina de dos formas: de manera tangencial, con Timotea, la mucama negra de Don Fermín, por Dante Quiterno, de 1932; agauchada, en Cirilo, el audaz, por Enrique Rapela, de 1939, y en Lindor Covas, el cimarrón, por Walter Ciocca, de 1954; y castrense, en El Cabo Sabino, (posteriormente Savino, al cambiar de casa editora) ilustrada por Carlos Casalla y escrita por Gustavo Solanas y Julio Álvarez Cao, de 1954; y protagónica, en Las aventuras del Negro Raúl, por Arturo Lanteri, de 1916; Página del Dólar, por Arístides Rechaín, de 1922-23; y Fulú, por Carlos Trillo y Eduardo Risso, publicada en Europa desde los setenta. Gociol y Rosenberg también listan figuraciones, durante los años treinta, en Blanca Nieve y Pío Pío, de Andrés Guevara; Alelí, negrito y Cosas de negro, de Manuel Martínez Parma; Betún, de Federico Daloisio; Mosquita Muerta, de Héctor Rodríguez; y, hasta los años cuarenta, Carne y uña, de Oscar Biotta. Durante los setenta está Skorpio de Ray Collins y Ernesto García Seijas; y en los ochenta, El cimarrón, de Ricardo Barreiro y Dose. A diferencia de la de Oesterheld, estas historietas carecen de índole historiográfica.

Revista Iberoamericana, Vol. LXXVII, Núm. 234, Enero-Marzo 2011, $41-57$
ISSN 2154-4794 (Electrónico) 
se refutan y la información para sustentar cualquiera de las posibles explicaciones es remota. ${ }^{12}$ De ahí la virtud del novel aporte de la historia según Oesterheld. Al tiempo que los resucita -eso sí, la imagen de Durañona nos remite a un soldado de uniforme, morral y carabina, adecuadamente provisto de menaje, tan a diferencia de las andrajosas tropas bolivarianas cruzando los páramos neogranadinos ${ }^{13}$-, el argumentista se encarga de acreditar, de manera un tanto artera, una probable explicación: los negros fueron empleados como carne de cañón, exterminados a punta de guerreo. En otras palabras, Oesterheld resucita al negro tan sólo para sepultarlo de una vez por todas. Su interés no es el de validar la posibilidad de la existencia de cosanguineidad, bastante diluida por cierto, en las poblaciones australes. Su objeto es aprovecharla para magnificar el grado de sevicia de las clases privilegiadas. A Oesterheld, el negro sólo le sirve como víctima o distracción; no alcanza a imaginárselo de otra forma. Para él, dista de ser un auténtico protagonista de la trama. En este relato, la negritud jamás asume una dimensión genuinamente redentora; por el contrario, se trata apenas de otro títere de la historia, sin capacidad de acción ni albedrío. El gran papel de la población negra no es luchar; es padecer y morir, sin ánimo de exoneración histórica. De vez en cuando, sin embargo, queda tiempo para divertirse; en la tercera viñeta dedicada a Juan Manuel de Rosas, Durañona ilustra a un grupo de negros... bailando, haciendo caso omiso del prejuicio. Trátese de la guerra de la independencia, las contiendas civiles o la Guerra del Paraguay, el caso es que el conflicto bélico surge como una especie de embudo en el cual van a parar todas las memorias y providencias de cualquier ancestro africano. La consabida libertad de vientres, tan argumentada en otros casos americanos -como el de México- ni siquiera sale a relucir en la historia según Oesterheld. Por supuesto, ¿̇en qué le beneficiaría en su ajuste de cuentas al establishment porteño? Acaso la negritud logre ser apenas una muletilla, un subterfugio para reiterar la homogeneidad racial, que no de clase, de sus coterráneos. En este sentido, resulta inconsecuente cómo 450 años

12 A este respecto, véase Los afroargentinos de Buenos Aires, de George Reid Andrews; Los negros en el ejército: declinación demográfica y disolución, de Morrone; e Identidades secretas: la negritud argentina, de Alejandro Solomianski. Con respecto al tema, el texto de Andrews es quizás el más certero, listando y analizando las factibles causas del ocaso demográfico: las bajas durante las guerras, el mulataje, las tasas de natalidad y mortandad de la población negra y la declinación del comercio de esclavos; de hecho, Andrews recuenta en detalle la estrepitosa caída de la población negra bonaerense a partir de 1850, año en el que todavía representaba cerca de un cuarenta por ciento de la población. El texto de Solomianski hace un concienzudo estudio de la represión de la afroargentinidad en la configuración del imaginario nacional, examinando una serie de textos decimonónicos y posteriores en los que la presencia afro es innegable. El texto de Morrone, pese a tratarse de un estudio pormenorizado de la población negra en el ejército, incluye información acerca de la gran cantidad de esclavos traídos a Buenos Aires durante el siglo XVIII -a veces muy superior a la traída a La Habana, Veracruz o Cartagena-, cuando ya un tercio de la población porteña era de origen africano. Hacia la misma época, la población negra en ciudades del noroeste argentino oscilaba entre el 46 (Salta) y el 64 (Tucumán) por ciento.

13 “El Ejército de la Patria Grande”, No. 24, del 30 de octubre de 1973.

ISSN 0034-9631 (Impreso) 
se apega a una versión conformista del mulataje o mestizaje argentino, sin postular una faceta más tangible de los hechos.

La vena maniquea de semejante representación no tarda en prodigar nexos entre la labor de Bernardino Rivadavia-quien era descendiente de negros, materia juiciosamente omitida en el relato; sus enemigos le apodaban "Doctor Chocolate"- y el linaje de entregadores de la patria_"Desde Mitre y Justo hasta Onganía y Lanusse"14-durante siglo y medio de dependencia económica y comercial. Argentina, al parecer, jamás ha disfrutado de un buen cuarto de hora. Siempre ha sido abusada, explotada y vilipendiada -como los negros en esta historia argentina-. La vena dramática de Oesterheld hace estragos en su complejización de una respuesta. En la Enfiteusis, ley promulgada por Rivadavia para tomarse lo más fecundo del territorio argentino, Oesterheld culmina su viaje a la semilla, identificando el verdadero origen de la clase hacendada. En las imágenes se cuela Perón, para recordarle al lector lo poco que importa que las tierras sirvan de campo de pasteo para millones de cabezas de ganado, cuando en realidad debieran de estar alimentando a muchos más. Es decir, aparte de drama, lo que sobra es la magnificación de la nacionalidad. Mientras Oesterheld aprovecha al negro para explicitar el sufrido carácter de las huestes libertadoras, los restantes elementos de la trama sustentan una versión alterna de la argentinidad, aunque fuertemente fundamentada en el relato oficial: el país como despensa inextinguible de recursos, violentada y desaprovechada por sus necios habitantes; su naturaleza, tan noble que alcanza para todos y sobra, dada la envergadura de sus dimensiones; y su clase dirigente, una casta traicionera que, o no ha sabido aprovechar el momento o llanamente carece de conciencia histórica, de la genial oportunidad otorgada por el destino para liderar la suerte de sus compatriotas. Como prueba magistral de esto último, Oesterheld revela el empleo doble de la tierra, un asunto muy porteño. Mientras por un lado grandes extensiones de campo quedaban a disposición de Rivadavia y sus amistades, por el otro servían como garantía para el primer gran empréstito de la patria argentina con la banca anglosajona -la firma Baring Brothers \& Co., progenitora del ulteriormente desaparecido Barings Bank. El primero de muchos, sugiere el guionista, pues ayer, como hoy, la dependencia financiera esperaba a la vuelta de la esquina. A partir de ahí, los británicos lograron encajarle al fisco argentino más de tres obligaciones, dice la historieta, y le obligaron a participar en empresas colectivas de índole bélica, como la Guerra de Paraguay, o dilataciones de la infraestructura con fines mezquinos, como los ferrocarriles argentinos. En otras palabras, aunque a primera impresión el guión de Oesterheld se empecine en fustigar las debilidades del Estado y cuestionar diversos aspectos del relato nacional, buena parte de la trama comparte el ensalzamiento de la argentinidad, de manera relativamente afín a los delineamientos de una construcción oficialista. Conclusión: la patria de seguro fue atropellada, pero lo que

14 “La Oligarquía Portuaria”, No. 25, del 6 de noviembre de 1973.

ISSN 0034-9631 (Impreso) 
se formula de ella, el talante magnánimo e indulgente de su naturaleza, por supuesto que raya en lo verídico. No puede haber otra forma de imaginársela. Los desaciertos de Rivadavia pueden ser objeto de crítica, pero el conflicto con el Brasil queda enmarcado por el arrojo de la flota gaucha que, con apenas unos cuantos barcos, logra detener el avance de los archisuperiores buques de guerra enemigos e impedir el bombardeo de Buenos Aires. De igual manera, los ejércitos de Alvear son representados como valientes despreocupados ante la desigualdad numérica: el hecho de que los brasileños cuenten con dos mil hombres más y de paso sigan contratando mercenarios alemanes les tiene sin cuidado. ${ }^{15}$ No sólo los vencen, sino que se quedan con sus armamentos y hasta con su marcha victoriosa -la composición encargada por el emperador brasileño aparece entre los despojos de la batalla-, que pasará a formar parte del imaginario de guerra del pueblo gaucho bajo el apelativo de "La marcha de Ituzaingó". De manera que la historia, tal y como es tratada por Oesterheld, se convierte de forma abierta en lo que suele ser (pese a las quejas de quienes la escriben): un menú. De ella, saca y se aprovecha el guionista según le venga en gana. Al final, si se pierde el Uruguay, si deja de formar parte de la gran patria de las Provincias Unidas, sin lugar a dudas es por causa de Rivadavia, quien en su desmedido afán por consolidar el poder de Buenos Aires, les ofrece la paz a los cariocas en vez de rematarlos. Muy ocupado estaba Rivadavia, asegura Oesterheld, en traer el ejército de vuelta, para contrarrestar factibles brotes de rebelión en el interior y complacer a sus prestamistas, los británicos, empecinados en lograr un buffer state (estado tapón) entre las emergentes naciones suramericanas. El contrasentido salta a la luz cuando en la siguiente entrega de la serie, dedicada al fin de Manuel Dorrego, el Uruguay es señalado como una república independiente ávida de integrarse de nuevo a las Provincias Unidas. ${ }^{16}$ En manos del guionista, tanto los territorios como los personajes adquieren matices acomodaticios, propicios para su lectura. El ajusticiamiento de Borrego a manos de Juan Lavalle reitera la oposición entre los prioritarios intereses del puerto y el desdén por las necesidades del interior del país.

Dentro de este esquema, otro gran aporte radica en la lectura que la historieta hace de personajes como Rosas, Martín Miguel de Güemes, Juan Facundo Quiroga y Francisco Ramírez. Para la historia oficial, Rosas, con su mazorca -su cuerpo de militantes fanáticos-, es el dictador sanguinario; para Oesterheld, es un redentor, quien le concede un respiro al interior y penaliza la importación de bienes británicos. En un abrir y cerrar de ojos, el guionista le da vuelta al asunto. Vindica a Rosas como a un hombre del pueblo, pese a haber nacido en una de las más acaudaladas familias del país. Le plantea como un auténtico defensor de los intereses de las masas, un ser que, pese a su rancio abolengo, fue capaz de irse a trabajar y convivir con los gauchos. Haciendo de

15 “La entrega del Uruguay”, No. 27, del 20 de noviembre de 1973.

16 “Dorrego", No. 28, del 27 de noviembre de 1973.

$\begin{array}{llllll}\text { Revista } & \text { Iberoamericana, Vol. LXXVII, Núm. 234, } & \text { Enero-Marzo } & \text { 2011, } & 41-57 \\ \text { ISSN 2154-4794 (Electrónico) }\end{array}$ 
cómplice, Durañona le dibuja de perfil, realzando su nobleza. En el caso de Güemes, el origen afortunado es análogo, pero a los catorce años la suerte está echada: el personaje será un hombre de acción. Durañona lo pinta como un aguerrido caudillo de provincia, inmerso en el fragor de la batalla. Para Oesterheld no cabe la menor duda: se trata de uno de los buenos. Su inmolación reitera la impiedad enemiga. Güemes muere desangrado, a causa de su hemofilia, pero a Oesterheld lo que le importa es quién disparó la bala. Lo de Quiroga, en cambio, se reduce a un recuento sucinto de su final, quizás con el objeto de evocar y cuestionar la obra de Sarmiento. Durañona le plasma con un balazo en el ojo. En manos de los historietistas, Quiroga, astuto y eficaz en la batalla, capaz de susurrar sus planes de guerra al oído de su alazán, emerge cual noble campeón de la unidad nacional. Entre este abanico de guerreros, el caso de Ramírez, creador de la República de Entre Ríos, es el más expansivo. Pese a su rol en la derrota de Artigas, Oesterheld le ensalza -de hecho, se ocupa de aclarar la ingenuidad de Ramírez al hacerle el juego al imperialismo, gracias a su enfrentamiento con Artigas-. Una vez más, con alarde de efectismo, se concentra en los momentos finales del héroe: su sangrienta decapitación y el sombrío recuerdo de su cabeza embalsamada sobre el escritorio de Estanislao López, circunstancia aprovechada por el dibujante para jugar de manera siniestra con las sombras. Esta serie de recuentos, tan viriles, amplifican el contraste entre la historia celebradora de Rivadavia, Mitre y Sarmiento, contra la cual el guionista desea arremeter, y el inventario histórico patrocinado por la historieta. Infortunadamente, proyectar a Rosas, Güemes, Quiroga o Ramírez a niveles tan encumbrados no hace sino reafirmar el carácter esquematizante de la visión del par de creadores, pues todo se reduce a un mundo finamente delineado en fuerzas opositoras. En este sentido, Oesterheld se aferra a una construcción simplista de la alteridad, con un mundo dividido en dos extremos demasiado nítidos: los buenos y los malos; la capital y el interior; la patria y el agresor, trátese de españoles, británicos o portugueses - por lo general, Oesterheld no los combina en un mismo episodio-. Nada queda por fuera. Tiene razón Kaminsky. No prestarle atención a los matices de la alteridad suele conducir a un callejón sin salida, en donde escasea el espacio para maniobrar y renovarse. De esta manera, al darse cada desplazamiento del sujeto, se elimina casi por completo el espacio de maniobra de una posible respuesta. Todo queda resuelto en extremos, precisado en polos opuestos y, al cabo de varios acercamientos, el mundo se sume en realidades encontradas. Una visión muy confortante, mas algo ligera, según hemos podido testimoniar en tiempos recientes. Con Oesterheld, este atolladero se evidencia de lleno. Su crítica del orden opresor es tan totalizadora y monolítica, tan esquemática, como la que los regímenes militares hicieron de los movimientos de oposición en Argentina. El cómic, dada su naturaleza esquematizante, puede contribuir con creces a este proyecto, sobre todo en manos de un público desacostumbrado a matizar ciertas diferencias. Como medio ilustrado, éste es uno de los riesgos implícitos de plantear una trama, de manera literal, en blanco y negro.

Revista Iberoamericana, Vol. LXXVII, Núm. 234,
ISSN 0034-9631 (Impreso) 
A estas alturas, resulta obvio que la terquedad de Oesterheld por ofrecernos una visión dualista del mundo impacta sobre todo tipo de temáticas en su producción para El Descamisado. Su visiónideologizante de las cosas no deja espacio para moderación alguna, de manera que cualquier representación se ve teñida o afectada por matices sectarios. En manos del guionista, lo identitario deviene bipolar. La historiografía de Oesterheld acusa los riesgos de una mirada binaria. Para la muestra, un botón. Si bien la historieta cosecha gran mérito por su diagramación de una negritud olvidada-aunque quepa señalar cierta intencionalidad en la efectividad de una borrazón colectiva-, también queda claro, como he sugerido con anterioridad, que la visión oesterheldiana de las masas esclavas no invita mayor desarrollo. La historieta conmemora el protagonismo de los esclavos en los ejércitos liberadores, mas acto seguido se apresura a ofrecernos una explicación cabal para su casi total ausencia en la población nacional contemporánea. Para efectos prácticos, la minúscula -en términos porcentuales- población caboverdiana y de otros orígenes patente en el gran Buenos Aires no cuenta mayor cosa. El episodio publicado el 8 de enero de 1974 despeja cualquier duda a este respecto. En este caso, como una auténtica novedad dentro de la producción cultural de la época, lo primario es la raza. La trama carece de prioridad argumental. Las circunstancias concretas, el momento de emancipación y la fecha de batalla son lo de menos. Lo clave es problematizar la condición de raza, circunstancia insólita en las historietas argentinas de la época, en las que las diagramaciones de la periferia -figuras africanas (“Tipp Kenya"), amerindias (El sargento Kirk, Ticonderoga) o asiáticas (Ernie Pike)- se amparaban en crónicas de aventuras, usualmente contextualizadas en coyunturas europeas o norteamericanas. El África de Carlos Roume, y el lejano oeste, el Pacífico y el Asia oriental de Hugo Pratt, imaginadas a lo largo de los años cincuenta y sesenta para ser publicadas en revistas como Misterix u Hora Cero, hablan de diferencia, mas tratan una experiencia en la distancia y mediada por realidades ajenas. En este sentido, no se remitían a un contexto argentino. Lo de "Negro", título dado a este episodio, es bien distinto. El protagonista es el negro Antonio, vendido por su dueño, un acaudalado bonaerense, al gobierno criollo. Preocupado por hacerse a una buena suma de dinero, el hombre le explica a Antonio que será libre al finalizar la guerra, y el esclavo sueña esperanzado con su liberación. La ofensiva, infelizmente, se alarga. Al personaje le toca lidiar con el mal de altura y el frío de la cordillera, el cual, según Oesterheld, "no es para negros”. En Chacabuco, como es de esperarse, el recluta Antonio muere atravesado por un bayonetazo. Al contemplar su cuerpo exánime de regreso a Mendoza, San Martín, tan generoso en su registro de los hechos, se apiada de su suerte ("Pobres negros... Nunca tuvieron nada. Ni pudieron llamar suyo el pan que comían. Ni siquiera el aire que respiraban.”) y reafirma su gran legado, con escaso asomo de ironía: los negros, aquellos mismos que jamás pudieron disfrutarla, le legan la libertad al continente. Para rematar, en la leyenda acompañante, Oesterheld nos recuerda que más de la mitad de los conscriptos del glorioso Ejército de

\footnotetext{
Revista Iberoamericana, Vol. LXXVII, Núm. 234,
ISSN 0034-9631 (Impreso)
} 
los Andes fueron negros. De esa manera, con la aseveración del aciago final de buena parte de la población esclava durante la campaña libertadora queda exonerada la historia argentina de cualquier sospecha de complicidad en materia de exclusión.

Si lo de la diferencia de raza recibe una puntada final con la dedicación de un episodio entero, la temática de género no se queda atrás. Oesterheld destina El Descamisado del 19 de febrero de 1974 al cubrimiento del papel de las soldaderas en marco de las guerras de independencia. Hasta este instante, en materia de representatividad femenina, el guionista y su dibujante se han circunscrito a esbozar la actitud displicente de las esposas e hijas de la dirigencia porteña, sumidas en sus acostumbradas diligencias. En la primera viñeta de este episodio, en cambio, aparece un trío de mujeres empuñando fusiles, aventurando un cambio de derrotero. De hecho, estos personajes hacen lo suyo por extender los confines de la patria: léase, matan indios a punta de balazos acertados. Las guerras decimonónicas se destacan, según machaca Oesterheld en no pocas ocasiones, por refrendar la buena fortuna de las clases dirigentes. Se trata, como en la mayoría de los conflictos bélicos, de una confrontación entre los desfavorecidos para resolver los asuntos de la clase acomodada. "Dos calvos peleando por un peine”, atinaría Borges muchos años más tarde, al describir la insensatez del conflicto malvino. Oesterheld cita a Prado, cronista de la época, para revelarnos que las mujeres "atendían a los enfermos, cocinaban, lavaban y remendaban las ropas, arreaban las caballadas”, de manera que, a excepción de los animales, sus responsabilidades se limitaban al consabido repertorio de tareas domésticas. Tras el fallecimiento de su compañero, el carácter abnegado de estas mujeres llegaba al extremo de aceptar como nueva pareja a un soldado enlistado en el mismo regimiento. Sus cuerpos se transformaban, de manera literal, en posesión estatal. En la historieta, no obstante, lo que a primera vista describe la naturaleza patrimonial del cuerpo femenino es festejado como voluntad de sacrificio por la patria, valga la pena preguntarse qué podrá tener proyectado semejante noción de colectividad para destinos tan desacordes. Para rematar, al igual que en el primer número de la serie, los historietistas no piensan dos veces antes de situar una imagen de Evita -una vez más, una fotografía, realzando el contraste entre los personajes y su dirigente- en el interior de una humilde vivienda tugurial. El nexo con el presente es obligatorio, independiente del grado de coherencia de la alusión. Jamás se contempla el nivel de desatino entre la imagen de la abanderada de los pobres, con el cabello platinado y un recio perfil, y la mueca cenceña de los habitantes del desventurado inmueble.

Intentar hacer un balance de la obra de Oesterheld, tan amplia y diversa, concentrándose en su fase más tardía, cuando su radicalización política había llegado a un vértice, plantea un difícil cometido. En cuestión de guiones para historietas, su producción es, dado su grado de profundidad, de lo más encomiable. Puede que sea imperfecta, como todo, pero su esmero al complejizar asuntos de índole identitaria dentro de un contexto altamente ideologizado, ajeno a fórmulas culturalistas, le garantiza un lugar en el canon narrativo argentino. De igual manera, su acogimiento como guionista

Revista Iberoamericana, Vol. LXXVII, Núm. 234, Enero-Marzo 2011, $41-57$
ISSN 2154-4794 (Electrónico) 
denota la dispar primacía de la grafía (sobre la imagen) en el contexto cultural gaucho, incluso en un medio dibujado, como la historieta. En llave con Leopoldo Durañona, el guionista hace gala de verbo crítico y embiste contra las potencias extranjeras y la clase acaudalada, a quienes concibe como esbirros de la argentinidad. Por lo tanto, resulta una verdadera ironía que, a la hora de lanzar juicios calificadores, Oesterheld, el legendario hombre de letras del medio gráfico argentino, adopte posturas y perspectivas tan acérrimas como a quienes fustigó. La gran diferencia radica en que Oesterheld llevó a cabo su labor con ingenio e intelecto, deleitando a grandes y chicos, a cambio de la tortura e infamia representativas de sus verdugos. De cualquier manera, su quehacer historietístico ilustra los riesgos de la idea de nación, inspiradora de pasiones y vinculada, nos apetezca o no, a una tradición de violencia, todavía demasiado concreta en muchísimos rincones de Latinoamérica. En un sentido análogo, éste es apenas un esfuerzo por lograr que la imagen se cuele por encima del imperio de la letra.

\section{BiBLIOGRAFÍA}

Andrews, George Reid. Los afroargentinos de Buenos Aires. Buenos Aires: Ediciones de la Flor, 1989.

Kaminsky, Amy. Argentina: Stories for a Nation. Minneapolis: University of Minnesota Press, 2008.

Marrone, Francisco C. Los negros en el ejército: declinación demográfica y disolución. Buenos Aires: Centro Editor de América Latina, 1995.

Oesterheld, Héctor Germán. Latinoamérica y el imperialismo, 450 años de guerra. Buenos Aires: Doeya y Viniegra, 2004.

Solomianski, Alejandro. Identidades secretas: la negritud argentina. Buenos Aires: Beatriz Viterbo, 2003.

Vargas Vera, René. “Charly García y el himno”. La Nación. Sección espectáculos. Buenos Aires, 28 de febrero de 2000.

(IS) 
